\title{
URGENSI CULTURAL APPROACH SEBAGAI METODOLOGI KEILMUAN DALAM PENDIDIKAN ISLAM KONTEMPORER
}

\author{
Samsul Hidayat
}

\begin{abstract}
Abstrak
Dalam pendekatan kultural, pendidikan Islam diarahkan pada persoalan autentitas dan perubahan budaya yang berkembang dimasyarakat. Diharapkan pendekatan ini akan membantu mahasiswa untuk memahami baik tradisi-tradisi yang pernah terjadi, berikut dengan segala karakteristiknya, maupun persoalan-persoalan kontekstual yang terjadi di masyarakat. Untuk masuk ke dalam wilayah pengembangan sikap penerimaan kultural yang sadar terhadap perubahan, maka melalui pendekatan kultural, diharapkan akan melahirkan sistem pendidikan yang lebih berorientasi ke masa depan (future oriented), menuju transformasi sosial yang humanis dan transcendental. Pendidikan Islam, mau tidak mau harus mengubah wajahnya yang selama ini hanya bersifat doktrinal-formalliteral ke arah studi dan pendekatan kebudayaan dengan semangat untuk mencari nilainilai fundamental keagamaan Islam, terutama bagi para mahasiswa dan kalangan muda yang memiliki tingkat resistensi tinggi dalam menghadapi modernitas dan era globalisasi saat ini.
\end{abstract}

Kata Kunci: sosial, budaya, kultur, agama

\section{A. Pendahuluan}

Satu hal yang patut disyukuri bahwa dengan pengembangan Perguruan Tinggi Agama Islam seperti IAIN/STAIN menjadi UIN di Indonesia, maka paradigma yang dibangun dalam pengembangan pendidikan Islam mulai bergeser dari pendidikan yang semula hanya menonjolkan peningkatan itba' syariat Allah dimana studi Islam dijabarkan dalam skala yang sempit, menuju itba' sunnatullah yang didalamnya mengakomodir natural sciences, social sciences dan humaniora (Muhaimin, 1999). Selama ini, apa dan bagaimana konsep dan wawasan serta prinsip kependidikan Islam tidak begitu dipermasalahkan. Namun, begitu sistem kehidupan sosial budaya dan peradaban umat Islam mengalami kemandekan dan kemunduran serta tidak mampu menghadapi tantangan perubahan sosial dan dampak globalisasi di 
masyakarat maka hal tersebut mulai dipertanyakan kembali.

Walaupun paradigma yang dibangun telah bergeser, namun kajian kependidikan Islam selama ini masih terkonsentrasi pada persoalan teoritis keagamaan yang bersifat kognitif semata, sementara metodologi keilmuan yang digunakan tak kunjung berubah antara pra dan post era modernitas yang kebanyakan lebih menitikberatkan pada aspek korespondensi-tekstual (Abdullah, 1998:49-65). Kajian-kajian kontekstual yang bersifat empiris seperti dengan pendekatan kultural justru masih sangat minim dan belum membudaya. Metodologi pendidikan Islam yang tidak kunjung berubah dari dulu sampai sekarang ini berakibat pada kurang mampunya lembaga pendidikan Islam dalam mengantisipasi fenomena-fenomena sosial-kebudayaan yang mengarah pada penyimpangan prilaku masyarakat seperti maraknya isu perkelahian pelajar, tindak kekerasan, kejahatan kerah putih, premanisme, konsumsi barang-barang terlarang dan sebagainya. Menjadi sebuah pertanyaan kritis, apakah kegiatan pendidikan Islam mampu berdialog dan berinteraksi dengan perkembangan zaman modern dengan segenap persoalan kulturalnya. Dalam keadaan demikian, masyarakat masih menunggu-nunggu kontribusi dan peran yang disumbangkan oleh PTAIN seperti UIN, baik secara moral maupun kultural dalam menghadapi persoalan tersebut.

Tulisan ini diharapkan dapat memberikan kontribusi yang berarti bagi penyegaran kembali pada pentingnya penerapan pendekatan kebudayaan dalam pendidikan Islam. Selain itu juga dimaksudkan agar berguna dalam pengembangan pemikiran pendidikan Islam yang sekaligus diaktualisasikan dalam bentuk perencanaan atau desain penelitian dengan pendekatan kebudayaan dalam pendidikan Islam kontemporer.

\section{B. Permasalahan Akademik}

Permasalahan utama dari kajian ini adalah mengapa cultural approach sebagai metodologi keilmuan dalam pendidikan Islam kontemporer belum membudaya dilingkungan PTAI, dan bagaimana bentuk penerapan pendekatan tersebut di lembaga perguruan tingga agama Islam?. Sehingga hal ini menarik untuk dicermati dan dirumuskan dalam identifikasi masalah sebagai berikut: apa yang dimaksud dengan 
pendidikan Islam, apakah makhluk cultural approach itu? apa urgensinya? bagaimana proses timbal balik antara pendekatan tersebut dengan kebutuhan masyarakat? dan dari mana memulai menerapkan pendekatan kultural ini dilingkungan akademik?

\section{Pendidikan Islam dan Pola Kajiannya}

Istilah pendidikan Islam secara sederhana dapat dipahami sebagai pendidikan yang dikembangkan dari nilai-nilai yang terkandung dalam sumber dasar ajaran Islam, al-Quran dan al-Hadist. Pendidikan Islam dalam pengertian ini dipahami sebagai pemikiran dan teori-teori pendidikan yang dibangun dan mendasarkan diri pada sumber dasarnya. Dalam realitasnya, pendidikan Islam tersebut dibangun dalam suatu visi; pemikiran, teori dan praktek penyelenggaraannya mempertimbangkan pengalaman dan khazanah intelektual muslim klasik serta mencermati situasi sosio-historis dan kultural masyarakat kontemporer (Muhaimin, 2002:29).

Literatur-literatur yang tersedia selama ini menunjukkan bahwa pola kajian kependidikan Islam memfokuskan diri pada beberapa kategori; 1) kajian-kajian sosio-historis pendidikan Islam; 2) kajian pemikiran dan teori pendidikan Islam; dan 3) kajian metodologis pendidikan Islam. Kegiatan-kegiatan pendidikan pada dasarnya sangat concern pada persoalan operasional, jadi sangatlah idealis dan utopis jika kajian yang dilakukan hanya berkutat pada persoalan fondasional filosofis. Kelemahan dari kajian pendidikan Islam seperti ini bisa juga terjadi sebaliknya, dimana penelitian sangat kaya dengan praktik/operasional namun lepas dari konsep fundasional atau dimensi teoritiknya (Muhaimin, 2002:v-vi).

Pendidikan adalah hal yang tumbuh dan berkembang bersamasama dengan pertumbuhan dan perkembangan masyarakat, bahkan merupakan media transmisi dan transformasi sistem dan nilai-nilai kehidupan sosial budaya dan peradaban masyarakatnya. Demikian pula pendidikan Islam, telah tumbuh dan berkembang bersama-sama dengan pertumbuhan dan perkembangan sistem dan nilai-nilai kehidupan sosial budaya dan peradaban Islam sepanjang sejarahnya, dan telah berfungsi sebagai media transmisi dan transformasinya secara efektif. Lemahnya pendidikan Islam dalam melirik fenomena sosial-agama 
dengan kacamata kebudayaan

merupakan sebuah problema

mendasar yang perlu segera dicarikan

solusinya sehingga tantangan

perubahan sosial yang begitu cepat dapat dihadapi dengan baik.

Pendidikan Islam harus mampu menjembatani persoalan perubahan sikap dan gaya hidup masyarakat yang semakin hedonis, konsumtif, dan eksploitatif dengan kebutuhan moralitas dan mentalitas keagamaan masyarakat yang memadai. Disini gaya hidup mencakup keseluruhan selera, kepercayaan dan praktik sistematis yang menjadi ciri suatu kelas, termasuk didalamnya adalah opini politik, keyakinan filosofis, keyakinan moral, selera estetis dan juga makanan, pakaian, budaya (Haryatmoko, 2003).

Pendekatan-pendekatan dalam pendidikan Islam yang masih bersifat kognitif, harus dikembangkan dan diberi warna dengan pendekatan yang lebih menyentuh kepada akar persoalan, sehingga pendidikan Islam mampu memenuhi kebutuhan dasar masyarakat, dan menjawab tantangantantangan baru di era multikultural ini. Pada era multikulturalisme yang menjadi titik tekan adalah keanekaragaman budaya dalam kesederajatan. Seperti yang dikatakan
Bhikhu Parekh (1997:167), multikulturalisme merupakan ideologi yang mengakui dan mengagungkan perbedaan dalam kesederajatan, baik secara individual maupun secara kebudayaan. Pendidikan sendiri merupakan basis atau dasar untuk menciptakan SDM dan pembentukan karakter suatu bangsa, dan merupakan pintu masuk bagi penerapan nilai-nilai multikulturalis (Abdullah, 2005:xix). Pendidikan, sebagaimana ditegaskan Ahmad Syafii Ma'arif (2001), sesungguhnya juga wahana paling efektif untuk internalisasi nilai-nilai demokrasi, pluralisme, dan inklusivisme.

Pendidikan Islam selama ini memang kurang bisa diharapkan kontribusinya dalam pembentukan masyarakat yang menghargai pluralisme, dan cenderung tidak menunjang demokratisasi. Apalagi, selama ini para tenaga pengajar di perguruan tinggi umumnya hanya menekankan ajaran agama yang bersifat teologis-dogmatis, (Mujani, 1995) sehingga makin membentuk chauvinisme rasa kebenaran pada agamanya sendiri. Dampaknya, pendidikan Islam menjadi kurang menyentuh aspek realitas sosial budaya yang sesungguhnya. 
D. Apakah Makhluk Cultural Approach itu?

Yang dimaksud dengan cultural approach atau pendekatan kultural adalah suatu metode kajian keilmuan dan atau penelitian yang menggunakan perspektif kebudayaan dalam menangkap realitas budaya, baik yang bersifat kasat mata (faktual) maupun yang berhubungan dengan fenomena abstrak kebudayaan (Endraswara, 2003:3). Kajian budaya merupakan studi tentang manusia dalam berbagai aspek; aspek biologis dan budaya manusia, aspek sejarah budaya, manusia sebagai bagian dunia, baik sebagai individu, kelompok, dan kajian budaya secara holistik (Schusky dan Culbert, 1967:23). Termasuk didalam studi kebudayaan adalah kompleksitas fenomena-fenomena agama. Dalam hal ini agama dapat dipahami sebagai suatu sistem kebudayaan (Geertz, 1973). Fenomena agama dianggap kompleks karena terkait dengan unsur sakralitas-transendentalnya, dan berhubungan langsung dengan fenomena agama dan sosial. (Abdullah, 2005:126) Untuk memahami fenomena agama diperlukan metodologi khusus, yaitu pendekatan kebudayaan yang diharapkan dapat menjelaskan dan menguraikan kompleksitas permasalahan tersebut. Dengan demikian pendekatan kebudayaan bertujuan untuk meningkatkan tingkat humanitas manusia, atau mengembangkan sikap dan perilaku humaniora manusia itu sendiri.

Memahami fenomena agama sebagai fenomena kebudayaan tidak bisa dilepaskan dari fakta empiris yang membuktikan bahwa agama sering mengalami kegersangan prinsip dan paradigma, serta hanya berkutat pada tataran normatif-formalistik, menjauh dari konteks masyarakat. Bahkan tidak jarang agama juga hanya dijadikan justifikasi atas klaim kebenaran aliran atau golongan tertentu. Tentu saja, fenomena tersebut menjadi problem terbesar yang dihadapi masyarakat beragama saat ini, tatkala agama mengalami krisis dalam dirinya sendiri. Agama hadir sebagai dogma dan dokumentasi ritual belaka. Sehingga, agama tidak mampu berinteraksi dengan dinamika sosial-masyarakat yang sedang mengalami krisis multidimensional. Konsekuensinya, agama tak mampu memberikan solusi alternatif bagi penyelesaian problem kemanusiaan. Untuk itulah diperlukan pemaknaan agama yang lebih dinamis, yang hidup ditengah obyektif komunitas manusia yang secara 
signifikan akan mempengaruhi

timbulnya interpretasi maupun

aktualisasi manusia-manusia

pemeluknya.

Setiap kebudayaan atau agama yang menganggap dirinya yang terbaik dan menekan yang lain dan menolak kontak dengan yang lain, cenderung akan memaksakan dan berkutat pada homogenitas mereka, sehingga mempersempit wilayah dialog kebudayaan, ruang kritis dan kemerdekaan berpikir. Padahal kebudayaan kita merupakan produk dari pengaruh-pengaruh yang berbeda, memuat untaian pemikiran yang berbeda dan terbuka untuk interpretasi yang berbeda (Parekh, 2000:168). Alih-alih menunjukkan kehebatan suatu kebudayaan, lebih baik menempatkan kebudayaan sebagai sesuatu yang tidak dapat dibandingkan dan harus dinilai dalam pengertian mereka sendiri. Setiap kebudayaan menunjukkan pandangan yang unik dan sangat kompleks tentang kehidupan yang baik, dan tidak dapat diukur dengan skala tunggal. Kebudayaan memiliki dimensi estetis, moral, literal, sosial, spiritual dn lain-lain. Ketika standar yang digunakan untuk menilai terlalu berbeda untuk disederhanakan menjadi suatu standar umum, ide tentang penilaian, perbandingan dan penggolongan semua kebudayaan akan membingungkan secara logika (Parekh, 2000:173) Dengan demikian, sekali kita memperhitungkan perbedaan kebudayaan, maka kita akan mempunyai sumber yang tersedia untuk membuat perbandingan antar budaya.

Kebudayaan merupakan sebuah proses, bukan suatu akhir, karena suatu proses maka selalu tumbuh dan berkembang. Dalam bahasa Umar Kayam (1986), kebudayaan dipahami sebagai "proses upaya masyarakat yang dialektis dalam menjawab setiap permasalahan dan tantangan yang dihadapkan kepadanya". Untuk itu konsep perantara perlu digunakan, yaitu yang melihat kebudayaan sebagai pedoman bagi kehidupan yang diyakini kebenarannya oleh para penganutnya untuk memahami lingkungannya guna memanfaatkannya bagi pemenuhan kebutuhan-kebutuhan kehidupannya. (Spradley 1972:6) Sebagai pedoman bagi kehidupan, kebudayaan berisikan pengetahuan dan keyakinankeyakinan, termasuk keyakinankeyakinan keagamaan. Keyakinankeyakinan yang menjadi patokan penilaian secara etika, moral, dan adab bagi tindakan-tindakan para 
penganutnya dalam pemenuhan kebutuhan-kebutuhan hidupnya sebagai manusia. Keyakinankeyakinan keagamaan yang menjadi patokan-patokan tersebut, menjadi membumi atau menjadi nilai-nilai budaya bagi penganutnya dan menjauh dari teks-teks suci karena yang bermakna adalah interpretasi dan hasil interpretasi dan bukan teks suci tersebut sebagai teks suci. Dalam keadaan demikian itulah agama, menurut Geertz, sebagai keyakinan keagamaan, menjadi kebudayaan atau lebih tepatnya menjadi nilai budaya. Clifford Geertz melihat agama merupakan sebagai keyakinankeyakinan keagamaan yang hidup dalam diri para penganutnya dan yang terwujud dalam kompleksitas kehidupan mereka sehari-hari. (Geertz 1973: 90) Yaitu kehidupan sehari-hari, baik yang sakral maupun yang profan. Sedangkan yang kudus itu ada dalam teks-teks suci agama yang melalui proses-proses interpretasi untuk pemahaman dijadikan acuan atau pedoman bagi keyakinan-keyakinan keagamaan dalam kehidupan penganutnya sehari-hari. Dalam keadaan demikian keyakinankeyakinan keagamaan yang hidup dalam diri para penganutnya adalah sama dengan kebudayaan dari para penganut keagamaan tersebut, dan sebaliknya, kebudayaan tersebut bagi para penganutnya adalah sesuatu yang sakral dan karena itu bercorak keagamaan.

Memahami agama sebagai kebudayaan akan memberikan pemahaman yang luas dalam mengkaji permasalahan-permasalahan sosial budaya masyarakat. Pendidikan Islam yang diharapkan dapat memberikan kontribusi dalam membangun sebuah kekuatan moral bagi masyarakat tentu harus berjuang keras dalam mencari pemecahannya. Dalam studi-studi keislaman, materimateri dan kajian keislaman yang didapatkan para mahasiswa cenderung melihat fenomena agama sebagai persoalan yang bisa diselesaikan hanya dengan pendekatan-pendekatan konvensional Perguruan Tinggi Agama Islam yang cenderung literal-doktriner. Akibatnya ketika berhadapan dengan permasalahan sosial budaya masyarakat, minimnya pengetahuan tentang pendekatan budaya membuat mahasiswa enggan untuk melakukan studi dan menggunakan pendekatan tersebut dalam kajian dan penelitian mereka. Ironisnya persoalan ini bahkan telah berlangsung sejak perguruan tinggi ini berdiri. 
Sulit untuk mencari kambing hitam disini, apakah yang keliru adalah para dosen yang mengajar tidak capable dalam bidang tersebut, atau kebijakan pemerintah dengan kurikulum titipannya, atau kurikulum yang tidak mengakomodasi studi-studi budaya, porsi jam studi yang tidak memadai, atau karena tidak adanya program studi yang khusus mengenai studi kebudayaan. Menurut pengakuan beberapa mahasiswa S3 UIN angkatan 2005/2006 alumni IAIN/UIN Sunan Kalijaga (baik S1 atau S2), bahwa mereka memandang cultural approach sebagai makhluk asing di Universitas Islam Negeri ini. Beberapa mahasiswa dengan latarbelakang jurusan syariah dan tarbiyah mengaku tradisi melakukan pendekatan kebudayaan sepertinya belum membudaya di kalangan mahasiswa karena sebagian besar mereka adalah para alumni pondok pesantren yang tidak dikenalkan dengan bidang tersebut. Faktanya, mata kuliah-mata kuliah yang berhubungan dengan metodologi seperti "Metode Studi Islam" pada jenjang $\mathrm{S} 1$ dan "Pendekatan dalam Pengkajian Islam" pada jenjang $\mathrm{S} 2$ yang saat ini masih diajarkan di semua fakultas ternyata belum mampu mengisi kekurangan yang telah lama dirasakan oleh lingkungan IAIN khususnya dan umat Islam pada umumnya.

Melakukan kajian pendidikan Islam dengan pendekatan budaya merupakan suatu upaya refleksi dari sebuah fenomena. Fenomena real yang terjadi di lapangan, yang bersumber pada diri manusia sebagai sentral komunitas baik secara individu maupun kolektif. Permasalahanpermasalahan dalam dunia pendidikan Islam sangat kompleks, apakah itu persoalan antar iman, antar agama, maupun antar budaya. Di era multikulturalisme ini, tantangan pendidikan Islam dihadapkan pada banyak persoalan, diantaranya bagaimana Islam mampu membaur dan memberikan warna bagi perdamaian, kerukunan dan toleransi di masyakarat. Pendidikan yang cenderung menekankan aspek normativitas tanpa mempedulikan aspek historisitas akan menjadikan anak didik berada dalam "tempurung kebenaran" dan apriori mereka masing-masing. Aspek-aspek yang menunjang tercapainya tujuan dari pendidikan Islam, mulai dari dosen, kurikulum, metode mengajar, sampai pada metodologi pengajaran harus mulai dibenahi dan patut menjadi perhatian serius bagi pimpinanpimpinan lembaga pendidikan di 
Indonesia saat ini. Jika tidak ingin dikatakan mahasiswa lulusan PTAI buta dengan cultural approach, dan tidak peka dengan persoalan sosial kebudayaan masa kini.

Pendidikan Islam, mau tidak mau harus mengubah wajahnya yang selama ini hanya bersifat doktrinalformal-literal ke arah studi dan pendekatan kebudayaan dengan semangat untuk mencari nilai-nilai fundamental keagamaan Islam, terutama bagi para mahasiswa dan kalangan muda yang memiliki tingkat resistensi tinggi dalam menghadapi modernitas dan era globalisasi saat ini. Pendekatan kebudayaan dalam pendidikan keislaman tidak lalu dimaksudkan untuk menghilangkan sama sekali kajian-kajian dan metodologi yang selama ini digunakan, tapi justru ingin melengkapi dan menyeimbangkannya sehingga apa yang disebut Amin Abdullah sebagai kompleksitas fenomena keagamaan dapat disikapi dan diatasi secara menyeluruh dan komprehensif.

\section{E. Desain Penelitian Kebudayaan}

Literatur tentang metodologi dengan pendekatan kebudayaan sesungguhnya telah banyak ditemukan di toko-toko buku, baik yang ditulis secara khusus maupun dalam bentuk kumpulan pendekatan studi seperti metodologi penelitian sosial-agama. Pendekatan kebudayaan memang memiliki sedikit kesamaan dengan pendekatan humaniora, sehingga perlu diperhatikan beberapa konteks kebudayaan, seperti yang dijelaskan Featherstone (Abdullah, 1999) sebagai berikut: Pertama, produksi kebudayaan, yaitu budaya sebagai ciptaan akan melebar ke bidang apa saja, sesuai dengan apa yang dibutuhkan dan diproduksi oleh masyarakat. Misalnya dalam budaya ekonomi, ketika seseorang mengkonsumsi sesuatu, maka disitu telah terjadi suatu negoisasi budaya yang luar biasa. Kedua, socio-genesis kebudayaan, dimana kebudayaan sangat berhubungan dengan lingkup (boundary) yang mengitarinya. Setiap wilayah sosial akan memproduksi budaya yang berlainan pula, dan tidak jarang antar budaya memiliki keterkaitan dan ketergantungan. Ketiga, psicho-genesis kebudayaan, dimana kebudayaan bisa berasal dari dorongan kejiwaan. Dengan demikian, konteks kebudayaan pada dasarnya sangatlah luas, mencakup seluruh aspek kehidupan manusia, termasuk agama.

Pada penelitian yang menggunakan pendekatan kebudayaan, fenomena 
kebudayaan yang ditangkap biasanya berupa kasus-kasus unik yang lebih mudah didekati dengan penelitian kualitatif. Penelitian menggunakan metode ini karena beberapa pertimbangan; a) menyesuaikan metode kualitatif lebih mudah bila berhadapan dengan kenyataan ganda, b) metode ini menyajikan secara langsung hakekat hubungan antara peneliti dan informan, dan c) metode ini lebih peka dan lebih dapat menyesuaikan diri dengan banyak penajaman pengaruh bersama dan terhadap pola-pola nilai yang dihadapi. (Moleong, 2002) Karena analisa kualitatitif lebih menekankan kepada data, (Suparyogo, 2001) maka untuk menyederhanakan seluruh data yang terkumpul sehingga dapat disajikan dalam suatu susunan yang sistematis, maka dilakukan proses pengorganisasian dan pengurutan data ke dalam pola, kategori dan satuan uraian dasar sehingga dapat ditemukan tema dan dapat dirumuskan hipotesis kerja seperti yang disarankan oleh data. Data yang masuk akan dipilih dan dipilah berdasarkan sub-sub pokok bahasan dalam rumusan masalah untuk kemudian diolah dan dimaknai.

Dalam pengumpulan data, peneliti sebagai instrumen pengumpul data, mengikuti asumsi kultural, dan mengikuti data. Disini peneliti harus fleksibel dan reflektif sekaligus mengambil jarak dengan obyek. Dalam beberapa teknik pengumpulan data, terkadang juga digunakan metode yang mengambil dan mendeskripsikan fakta lapangan sebagaimana adanya. Melalui observasi dan wawancara mendalam (indept-interview) Peneliti dapat terlibat langsung dengan obyek penelitian (partisipant observation) atau pengamatan dilakukan secara murni, dalam arti peneliti hanya mengamati tanpa melibatkan diri dengan aktifitas kebudayaan yang berlangsung (Abdullah, 2002) Namun demikian peneliti tetap dapat menafsirkan fenomena budaya yang ditemukan, tanpa berusaha memanipulasi dan mengontrolnya, dan lebih menekankan logic in action. Sementara wawancara dilakukan dengan pihak yang dipandang memiliki kapasitas untuk memberikan informasi mengenai fakta kebudayaan.

Perspektif yang digunakan dalam pendekatan kebudayaan biasanya cukup beragam. Pada model dan teori klasik, penelitian kebudayaan biasanya 
mengunakan beberapa teori seperti evolusionisme, difusi kebudayaan, fungsionalisme kebudayaan dan fungsionalisme struktural. Teori-teori modern dalam penelitian kebudayaan banyak menggunakan teori strukturalisme, tafsir kebudayaan, etnosains dan etnometodolgi. Sementara teori-teori postmodernisme dan postkolonial penelitian kebudayaan menyangkut dasar-dasar postmodernisme, teori-teori kajian (pluralitas makna, out of context, langkah kajian), dan kajian postkolonialisme (Endraswara, 2003)

\section{F. Darimana Memulainya?}

Dibawah ini ditawarkan beberapa orientasi yang dapat menjadi prioritas dan penekanan dalam mengambil langkah-langkah konkrit bagi penerapan cultural approach sebagai metodologi keilmuan dalam pendidikan Islam kontemporer, yaitu:

\section{Orientasi Mahasiswa}

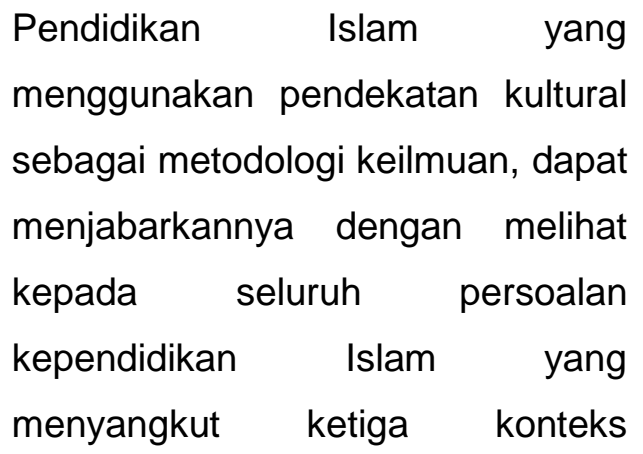

kebudayaan tersebut. Pendekatan kultural biasanya lebih memilih studi lapangan dalam model penelitiannya. Pemilihan studi kasus dalam penelitian biasanya lebih menarik karena peneliti memasuki wilayah yang unik dan menantang. Memang akan menjadi sedikit kendala bagi para mahasiswa yang terbiasa duduk di meja tulis dalam melakukan penelitian, artinya pendekatan yang mereka gunakan cenderung kepada penelitian pustaka. Atau karena biaya yang terbatas, karena mahasiswa UIN dikenal umum sebagai mahasiswa kelas menengah kebawah. Namun demikian bukan berarti mahasiswa harus mengurungkan niatnya dalam melakukan penelitian sosial-budaya tersebut karena obyek penelitian dapat ditemukan disekitar kampus mereka, bahkan dilingkungan kost mereka sendiri. Sebagai contoh, bagaimana kasus orang tua beda agama dalam menentukan pendidikan agama bagi anakanaknya, atau bagaimana efektifitas pendidikan agama di sekolah bagi pencegahan penyimpangan seksual anak-anak jalanan di Yogyakarta. 


\section{Orientasi Pengajar}

Model pengajaran dan bahan ajar yang diberikan oleh para dosen seharusnya lebih variatif sehingga memberikan tawaran kepada mahasiswa untuk memilih pendekatan dalam penelitiannya, dalam hal ini dari pendekatan teks menuju pendekatan konteks (empiris). Para dosen juga harus membekali diri mereka dengan informasi-informasi aktual dari permasalahan masyarakat kontemporer, berikut teori-teori kebudayaan mulai dari yang klasik, modern sampai post-kolonial, sehingga ketika memberikan wawasan pendekatan kepada mahasiswa, terutama dalam pendekatan kebudayaan, diharapkan dapat menggugah keinginan dan dorongan bagi mahasiswa untuk melakukan penelitian yang dimaksud. Para pengajar juga perlu diberikan tambahan pengetahun secara terstruktur baik dalam bentuk seminar, lokakarya atau pelatihan mengenai teori dan aplikasi metodologi dengan pendekatan kultural. Lebih menarik jika diadakan suatu kompetisi dan penghargaan dalam penelitian kebudayaan untuk memberikan motivasi bagi para pengajar dalam melakukan penelitian-penelitian yang serupa.

\section{Orientasi Pimpinan PT dan Kurikulum}

Tampaknya belum ada tanda-tanda Perguruan Tinggi Islam Negeri seperti UIN Sunan Kalijaga untuk membuka fakultas khusus yang mengakomodir masalah kebudayaan seperti Program Studi IImu Budaya. Namun demikian karena fokus tulisan ini pada pendidikan Islam secara keseluruhan, kalaupun belum ada rencana ke arah pembentukan fakultas atau program studi baru, maka paling tidak muatan kurikulum yang mengenalkan mahasiswa kepada metodologi keilmuan seperti mata kuliah Metode Studi Islam (S1), atau Pendekatan Dalam Pengkajian Islam (S2) dapat diperbanyak sistem kredit semester (sks) nya. Hal ini dimaksudkan agar mahasiswa betul-betul yakin dan menguasai teori yang akan mereka gunakan dalam penelitian-penelitian mereka dan lebih jeli dalam melihat fenomena sosial-budaya di lapangan. Pada orientasi kurikulum ini, pimpinan lembaga PTAI seharusnya lebih berani dalam 


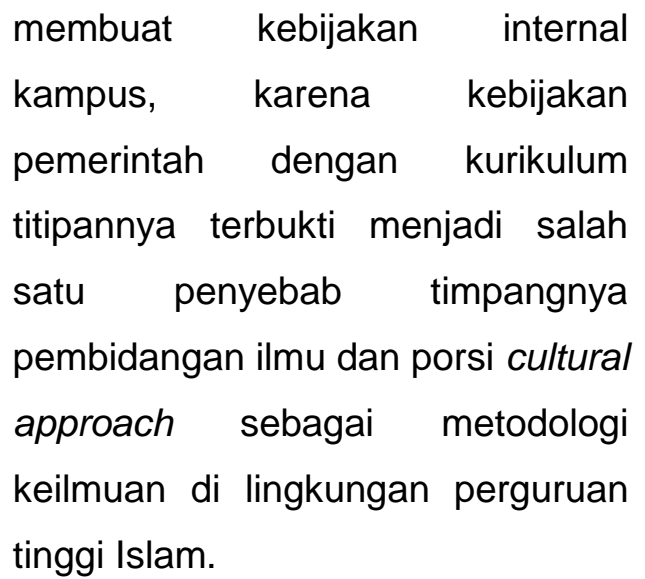

\section{G. Kesimpulan}

Hingga saat ini, pendidikan Islam masih menghadapi problem yang mendasar, diantaranya adalah seputar penggunaan pendekatan sebagai metodologi keilmuan. Jika problem tersebut tidak segera ditanggapi secara serius dan berkelanjutan, maka peran pendidikan Islam akan kehilangan daya tariknya. Idealnya, pendekatan-pendekatan yang digunakan sebagai metodologi dalam pendidikan Islam diakomodir secara integral, baik melalui pendekatan historis, psikologis, sosiologis, kultural maupun estetik. Dalam pendekatan kultural, pendidikan Islam diarahkan pada persoalan autentitas dan perubahan budaya yang berkembang dimasyarakat. Diharapkan pendekatan ini akan membantu mahasiswa untuk memahami baik tradisi-tradisi yang pernah terjadi, berikut dengan segala karakteristiknya, maupun persoalan- persoalan kontekstual yang terjadi di masyarakat. Dalam hal ini saya sepakat dengan Clifford Geertz yang menekankan bahwa agama harus menegaskan sesuatu, jika agama tidak mau disebut sebagai kumpulan praktik-praktik yang hampa makna dan sentimen-sentimen konvensional yang menjadi rujukan moralisme, walaupun faktanya masih sebatas komoditas dan bahan pembicaraan.

Sangat disayangkan jika kecendrungan di kalangan lembagalembaga pendidikan Islam sekarang ini, lebih menekankan proses teaching, proses pengajaran ketimbang proses learning, proses pendidikan. Dengan demikian proses pengajaran, hanya mengisi aspek kognitif dan tidak membentuk pribadi dan watak. Untuk itu diperlukan rekonstruksi perumusan kembali makna pendidikan. Seharusnya proses pendidikan Islam yang kita tempuh lebih menggunakan term ta'dib ketimbang tarbiyah, karena ta'dib lebih mengarah kepada inkulturasi, proses pembudayaan, tidak sekedar proses intelektualisasi. Melalui proses ta'dib maka akan muncul dari sistem pendidikan manusia yang betulbetul berbudaya, berkarakter dan berakhlak. Untuk masuk ke dalam wilayah pengembangan sikap penerimaan kultural yang sadar 
terhadap perubahan, maka melalui pendekatan kultural, diharapkan akan melahirkan sistem pendidikan yang lebih berorientasi ke masa depan (future oriented), menuju transformasi sosial yang humanis dan transendental.

\section{H. Daftar Pustaka}

Abdullah, Amin. Problem EpistemologiMetodologis Pendidikan Islam. Dalam Abd. Munir Mulkhan, et.al., Religiusitas Iptek. Yogyakarta : Pustaka Pelajar.2005 Kesadaran Multikultural: Sebuah Gerakan "Interest Minimalization" dalam Meredakan Konflik Sosial, dalam M. Ainul Yaqin, Pendidikan Multikultural, Cross-Cultural Understanding untuk Demokrasi dan Keadilan, Yogyakarta: Pilar, 2005.Pendidikan Agama Era Multikultural-Multireligius. Jakarta : PSAP.

Abdullah, Irwan. 2002 Metode Penelitian Kualitatif, Hand out, Yogyakarta : Magister Administrasi Publik UGM.

Endraswara, Suwardi. 2003 Metodologi Penelitian Kebudayaan. Yogyakarta : Gadjah Mada University Press.

Geertz, Clifford. 1973. The Interpretation of Culture. New York : Basic Book.

Haryatmoko. 2003. "Menyingkap Kepalsuan Budaya Penguasa:
Landasan Teoritis Gerakan Sosial Menurut Pierre Bourdieu", dalam Majalah Basis Nomor 11-12/Tahun ke-52. Yogyakarta : Kanisius.

Kayam, Umar. 1986. Tentang Pembudayaan Koperasi, makalah untuk "Seminar Menggali Nilai Budaya Bangsa", Yogyakarta.

Ma'arif, Ahmad Syafii (et. al). 2001. Tulus Seperti Merpati, Cerdik Seperti Ular. Yogyakarta : Kanisius.

Moloeong, Lexy. $2002 . \quad$ Metodologi

Penelitian Kualitatif, Bandung : Remaja Rosdakarya.

Muhaimin, et.al. $2002 . \quad$ Paradigma

Pendidikan Islam. Bandung : Remaja Rosdakarya.

Muhaimin. 1999. Tema-tema Pokok Dakwah Islam di Tengah Transformasi Sosial. Surabaya : Karya Abditama.

Parekh, Bhikhu. $1997 . \quad$ "National

Culture and Multiculturalism", dalam Kenneth Thomson (ed.), Media and Cultural Regulation, London : Sage Publications.

2000. Rethinking Multiculturalism: Cultural Diversity and Political Theory, Cambridge, Mass : Harvard University Press, 2000.

Schusky, Ernest, L dan T Patrick Culbert. 1967. Introducing Cultural. New Jersey : Prentice-Hall, Inc, Englewood Cliffs. 
Spradley, J. 1972. Foundations of Cultural

Knowledge, in Spradley, P (ed),

Culture and Cognition: rules, maps, and plans. San Francisco:

Chandler Publishing Co. 